\title{
Exposure to and usage of e-banking channels
}

\section{Implications for bank customers' awareness}

and attitude to e-banking in Nigeria

Henry Inegbedion

Department of Business Studies, College of Business and Social Sciences, Landmark University, Omu Aran, Nigeria

Emmanuel Edo Inegbedion

Directorate of Physical Planning Department, National Broadcast Academy, Lagos, Nigeria

Samuel Jesuorobo Osifo

Department of Business Administration, Faculty of Management Sciences,

University of Benin, Benin City, Nigeria, and

Sunday C. Eze, Adebanji Ayeni and Olamide Akintimehin

Department of Business Studies, College of Business and Social Sciences,

Landmark University, Omu Aran, Nigeria

\section{Abstract}

Purpose - Emphasis of previous research on e-banking has been on factors that influence its adoption or constraints to the adoption or the extent to which customer awareness influences its adoption. This study investigated "Exposure to/usage of e-banking channels: Implications for customer awareness and attitude in Nigeria". The purpose of this paper is to determine the extent to which consumers' exposure to and usage of e-banking channels influence their awareness and attitude towards e-banking in Nigeria. Design/methodology/approach - The study used the quantitative research design; specifically, the conclusive research design was used and data collection was done through the survey method. The population of the study consisted of the customers of EcoBank, First bank and Zenith bank in Edo, Kogi and Kwara states of Nigeria. A structured questionnaire was used to elicit the desired data from 480 respondents selected from 30 branches of 3 banks in two states. One sample t test was used to test for significance of the usage of e-banking channels to customers' awareness and attitude towards 
e-banking. Subsequently, regression analysis was performed to determine the predictive power of the

e-banking channels.

Findings - Customers' exposure to and usage of ATM, internet banking and mobile banking has significant influence on consumers' attitude towards e-banking in Nigeria. In view of the findings, a modified model of customer usage and attitude towards e-banking in Nigeria is proposed.

Research limitations/implications - The customer's inability to exercise absolute right on the banking option to use at all times and the non-inclusion of other channels of e-banking whose usage can influence consumers' awareness and attitude towards e-banking.

Practical implications - The need for financial institutions, especially banks, to expose their customers to e-banking channels to demystify their fears as well as increase their awareness and thus influence their attitude to e-banking.

Social implications - Exposure of bank customers to e-banking will reduce cash transactions and thus help to significantly reduce social vices associated with physical cash, especially armed robbery. 